ЖАНРОЛОГІЯ

DOI: $10.31861 /$ pytlit2018.98.175

УДК 821.161.2-1.09

\title{
AN ENDEAVOR OF FREEDOM: MODERN ANTHOLOGIES OF UKRAINIAN FREE VERSE
}

\author{
Nataliia Naumenko \\ orcid.org/0000-0002-7340-8985 \\ lyutik.0101@gmail.com \\ Department of Foreign Languages for Specific Purposes \\ National University of Food Technologies \\ 68 Volodymyrska St., 01601, Kyiv, Ukraine
}

\begin{abstract}
The main problem of researching the semantics of free verse and its translations is that every literary critic is free to look at this intricate genre, choosing one's own set of tropes and figures to interpret it in written form. These facts were considered in this study of original Ukrainian free verse works and their interpretations, regarding the specific treats of languages to use. The anthology Вільний вітер. Волен вятър published in Kharkiv in 2017 became a material for this research. This issue makes a good opportunity for one reader to get acquainted with Bulgarian culture, and for another to actualize their knowledge about this country on Black Sea coast. The $20^{\text {th }}$ century free verse writing represents quite active and flexible use of natural philosophical imagery in the artistic texture of the poems. These are different functions for it to fulfill (from decorating the lyrical narration up to expression of an essence of the work), stylistic means, and formation of the new connotations on the base of traditional meanings. Studying the interpretations of traditional genres and their poetics in compositional and lingual dimensions of both Ukrainian and Bulgarian free verses (those included into Вільний вітер) allowed seeing the fact: the more the author gets into the internal world of the character and one's relationships with nature, the wider becomes the circle of meanings for the cultural conceit, image, and symbol. Furthermore, the larger research field gets opened for comparison of aforesaid meanings in various languages, not only Ukrainian and Bulgarian.
\end{abstract}

Key words: Ukrainian and Bulgarian poetry, free verse, translation, anthology, style, genre, language.

(C) Науменко Н., 2018 
The main problem of studying free verse and its translations is that each of the literary critics may observe this genre one's own way and therefore define the array of its tropes and figures. Oleksandr Zhovtis, one of the prominent researchers of free verse, explained the composition of such a verse by the fact of "repetitiveness of the phonetic essences of various levels that replace each other; those recurrent components... may be a phoneme, a syllable, a foot, a stress, a clause, a word, a word combination, and a phrase" [8, p. 118]. Therefore, the scholar made the important conclusion that free verse would be naturally adopted in any language thanks to 'changes of repeating units' [7, p. 15], what became the theoretical statement to further research of translating free-verse works.

In contradiction to Zhovtis's thesis, Olha Ovcharenko stated in 1984 that non-regulated and non-predictable changes of repeating units would be immanent for free verse and therefore make its reading and perception complicated. "Whosoever will read a book of free verses to the end?" Volodymyr Bazylevs'ky appealed to researchers. Otherwise, we tend to think that the repeating units arrange the verse text just by their changing, and henceforth, they fulfill the rhythm-making function instead of regular meter and rhyme, for instance. Thus, the perception of free verse gets easier for both the researcher and the average reader. The moment of spiritual insight is also important in this process, and its consequence is the legibility of such sort of poetry [2, p. 230].

The Ukrainian literary critic Oleh Haynicheru was the first to turn directly to the problem of free verse translation. Particularly, he studied the system of tropes and figures in free verse and its interpretations. Having started from the statement by Volodymyr Rossels, "Some wellknown means of classical versification - like poetic lexicon, inversions, metaphors and similes, and any verse meter for the background - are alien for free verse" [13, p. 28], O. Haynicheru mentioned that free verse would reject neither inversion nor any other figure, but just limit their usage within the very new poetic system according to the principles of esthetic motivation [4, p. 186]. All of the features revealed were considered in researching the original free verse and its interpretations, regarding the specifications of languages.

Upon characterizing the role of free verse in development of a poet's individual style, we should mention its ambivalent nature. An 
author happens either to dedicate a certain period of one's creativity to free form, improving it from poem to poem, or use it sporadically - when one feels one's thoughts and emotions to be expressed just in the free manner, which is comprised and otherwise open, giving a reader an impulse to mutual creation. Anatoliy Moysiyenko at the early 2000s emphasized that composing the Ukrainian free verse anthology would be a crucially relevant affair, as it was done in 1990s - in Russia (The White Square, 1992; Nine Dimensions, 1999) or certain regions of Ukraine.

A. Moysiyenko used to thinking that the great deal of free verse writers in our country makes the studies of this poetic phenomenon more complicated; however, it is not an evidence of the poverty of today's free verse field, but a marker of pretty wide amplitude of creative searches and inevitable progress in Ukrainian poetry. Now, taking into consideration the apparition of enormous amount of free form works (both pure masterpieces and graphomaniac writings), the task to compose such an anthology seems to be a real endeavor of freedom.

The anthology Вільнии вітер. Волен вятьр (hereinafter named The Free Wind) published in Kharkiv in 2017 became a material for this research. This issue makes a good opportunity for some readers to get acquainted with Bulgarian culture, and for others to actualize their knowledge about this country on Black Sea coast. Some fifty or sixty years ago, Ukrainians were fond of the variety songs by Bulgarian authors and performers like Emil Dymytrov (Letter to My Mother), Lily Ivanova (The Sea of Youth), Irena Chmykhova (Full Moon), Toncho Rusyev (You, You, You), brothers Blagovest and Svyatoslav Argirovs (Kalimba de Luna, Bulgarian version). The plays by outstanding Bulgarian playwrights, for instance Peyo Yavorov's At the Foot of Vitosha, Nedyalko Yordanov's Mata Hari and Murder of Gonzago, had a great success on the stages of prominent Ukrainian theatres.

Therefore, the recently issued poetic anthology, as for Mykhaylo Sydorzhevski - the author of the foreword, is a "specific exchange of visiting cards by two neighboring peoples, two cultures, which are somewhat similar and somewhat different" [3, p. 4]. Hence, there is important to look at the essence of free verse interpreted by the $20^{\text {th }}$ century Bulgarian poets. For example, Veselyn Khanchev hypothetically defined free verse as the form to 
...be unchained and thereinafter closer to ordinary human language, built on associative, figurative thought and on the internal energy of a word. It will gradually find its own logics and its own rhythm which are similar to logics and rhythm of our modernity [1, p. 260].

As for Lyuben Lyubenov, free verse is different by larger sensual density of phrases, thanks to the absence of words and idioms obligatory used in metrical verses, and also of spare pronouns, adverbs and adjectives to fulfill the rhyme (this problem is evident for Ukrainian and Bulgarian languages, different from English with its own typical rhyme chains). That is why the well-written free verse sounds maximally natural [9, p. 514]. Konstantyn Yelenkov saw free verse a monologue for the poets to turn to "the Space, the Universe, to World... or merely to the Sea" [6, p. 17].

Therefore, Bulgarian cultural paradigm represents the following aspect of free verse poetics: it is a human speech organized in everyday language, but addressed to extraordinary audience - nature first of all. This became the key point in the majority of verses published in the anthology.

Dmytro Pavlychko said,

Such poetry has got the confessional intention, it cannot stand any decorations, spare words, and emotional splashes. Its shape is the free notation of the thought; and its spirit is the truth that does neither like to go in splendor nor annoy you by its nudity [11, p. 3].

This comprehension of free verse's nature might, as Mykola Khvyl'ovyi would tell, appear thanks to staunch movement 'through the profound culture of the classical verse,' which has been successfully accomplished by D. Pavlychko. His aforesaid statement may also be taken as the definition of free verse as a whole, because the correlation between shape and sense of a poetic work is precisely outlined over there.

The $20^{\text {th }}$ century free verse writing represents quite active and flexible use of natural philosophical imagery in the artistic texture of the poems. These are different functions for it to fulfill (from decorating the lyrical narration up to expression of an essence of the work), stylistic means (scrutinizing the natural phenomena to the states of human soul, 
antitheses of natural images), and formation of the new connotations on the base of traditional meanings.

Vernal Associations by Mykola Martyniuk are the first example to prove this thesis. His vers libres can remind the well-educated reader about the ancient Japanese anthology Manyoshu, or The Collection of Myriads of Leaves. Three miniatures to be included into The Free Wind do not only show the spring coming, but also poetize the man's archetypal memories of this joyful moment (this is to notice that spring coming is a starting point for the new year - for instance, Navruz in Moslem calendar):

\author{
У ранніх весен \\ тривожні \\ сни \\ пропахлі \\ підсніжниками [3, p. 98].
}

There were only several moves of a brush to depict a snowdrop the traditional symbol of the nature awakening. Otherwise, there are also evident two points: anxiety - the specific stress situation connected with sleep carrying birth, and the past - the prototype of the future.

The second miniature combines two images of the other paradigm the family. There are 'spring the woman' and 'sun the love' to create summer. A quite unusual motif, a connection of birth and aging, gets transformed from the second poem into the third: "Розхристана ніч/ принесла у сповитку / туман / а він на ранок / посивів" (in Bulgarian: “Разгърдената нош / донесе в пелена / мъгла / а на сутринта / тя посивя", transl. by Dymyter Khristov [3, p. 99]).

The subtitle 'from the cycle' allows the reader to suppose the existence of other 'vernal associations,' or maybe their absence? Nobody knows but the author. However, the three-verse collection confirms the idea of struggle and unity of the opposites, the idea of circulation of Yin and Yang by each of its words.

The Oriental mood of the verses is apparent in the hidden metaphors: deep winter - the whole white color; spring - the combination of light-blue and green with brown. Having been deprived of the background, the subject (a flower, a leaf, or a tree) gets figuratively taken out of its environment, and introduces into the white 
field of the picture accompanied by verses. This is the main principle of Chinese graphics, guohua, - the unity of picture, lyrics, and calligraphy.

The Japanese-styled answer for this poetic epistle may be seen in the following Bulgarian free verse written by Antanas Vanchev de Tracie:

Старицата бавно, предпазливо / Пресича улищата. / Дъждът се излива. / Верният чадър, / Износен и избелял, / Предпазва избелелите ии коси. / Ах, това бавно, премерено / Въздигане към вечността! [3, p. 164].

Poetics of the spell allows many researches to consider this ancient folklore genre one of the prototypes for free verse. The spell reflects the aspects of Pagan worldview (personification of natural elements, celestial bodies, live entities, things etc.). Bohdana Hayvorons'ka, the author of the novelty poetic spells, uses the specific architectonics of the sentence - the words within a separate line are put down with hyphens, which may be a tribute to the traditions of antique manuscripts with no spaces between words and with enjambments for punctuation marks.

Повернися-зюйде-до-мене-обличчям-суничним (чаклую)

Поверни-на-моє-обличчя-очей-чорниці (чаклую)

Я-літаю-як-ластівка-як-черниця:

Ластівка-як-черниця (крила горять і книга)

У-мене-більще-немає-магічних-сил (зупинилась ріка що годує море)...

$[3$, p. 40].

Studying the interpretations of archaic folklore genres and their poetics in the language of contemporary Ukrainian and Bulgarian free verse - particularly published in The Free Wind - allows us to see: the deeper goes the author into the internal dimensions of a character's life and one's relations with the environment (expressed in the shape of the spells), the wider becomes the circle of the meanings for the certain cultural conceit, image, or symbol. It is remarkable that in the translation of the verse cited above, Vanya Angelova has replaced the originally used German word 'Süd' (зюйд) to name the South wind by autochthonic Bulgarian one, "южняко", and therefore made the poem closer to archetypal initials. 
Thanks to this, the associative fields created by traditional images within the poem based on folklore genre can get the common tangent point in syncretic content. This is why the verses by Vasyl Holoborod'ko, the recognized master of free-verse Ukrainian fairy-tales, riddles and spells, so consequently appeared in The Free Wind. His vers libres contain the echoes of ancient ritual of vernal calling-on the birds:

Соловейку,

Ти так гарно співаєи,

Ти літаєш усюди,

Слухаєш, як все звучить:

Як жебонить струмок по каміниях,

Як шелестить листя від повіву вітру,

Як дзвенить крапля роси ураниі,

Та й наслідуєш їх своїм голосом... (Look and Listen [3, p. 44]);

reflections about the relationships between not only people, but also words:

Діалог завжди відбувається

У оточенні страху,

Що відповіді не буде -

Тоді діалог не відбудеться... (The Conversation [3, p. 46]);

interpretations of antique philosophical conceits:

немає гілки

на якій сиділа пташка

ая ж якраз ї̈ збирався тобі показати...

немає війська Ігоря

тільки й можна впізнати ту місичину

за зграєю вороння

щзо укриває поле

ніби після щойної поразки (Voids Unfilled [3, p. 46]).

The childlike vision of the nature, represented in this poem, allows the researcher to talk about ostrannenie as one of the conceptual means in V. Holoborod'ko's poetics. This was so successfully transferred in Vanya Angelova's translations, for example, in Look and Listen: 
Славею, / ти пееш толкова красиво, / летиш навсякъде, / слушаш различни звуци: / как ломоти потокът по камъчетата, / как шумолят листата от польха на вятра, / как звънят капките утринна роса, / и ги повтаряи с гласа си. // Ако поне веднъж / беше чул как говори моя възлюблена / и запееш така, както тя / пее в пролетния тани, / ти би пял още по-красиво / и всички биха спрели, да те послушат [3, p. 45-47].

All those features permitted to define Holoborod'ko's free verse as the completely associative poetry of abstract notions with real meanings otherwise. His verse libres are congenial to Ukrainian folklore poetry thanks to creative translocations of its images, symbols, and attributes of popular feasts (particularly, to the dialogue between the speaker and the objects of nature, shaped in spell forms). Such translocation requires just free (folksong, colloquial, miraculous) tones of narration to give the reader an impulse to mutual creativity and search for the sense of life.

This mutual creativity was furthermore expresses in spell-like verse Melody of Green Colors ("Мелодия в зелено") by Latinka Zlatna. Its tonality is similar to early intimate lyrics by Lina Kostenko and Vira Vovk's Love Letters of Princess Veronica...:

Накъде си се забързал, Приятелю? / Още си в началото на есента... / Думите ти са шепот на листа. / Диханието ти изпълва въздуха / с аромат на цветя... / Не ми ли вярваш? / Ето ти ключа на Лятото! / Долината ти е в зелено [3, p. 174].

Symbolism of punctuation marks had obtained great significance in free verse. It is well-known that the main function of a punctuation mark in a poetic work is to indicate the pause and its duration. According to M. Gruns'ky and M. Myronenko, the outstanding researchers of punctuation semantics in literary text, "punctuation marks show us where make a pause - now longer, now shorter, - where rise the voice and where lower it, which intonation use to pronounce a phrase, etc. They look a little bit like notes of music" [5, p. 3].

Therefore, punctuation itself is aimed at making up the special intonation of a poetic text; this is why its role in the free verse should be outlined. Punctuation shaping of a verse line in the free verse is divided into three kinds: firstly, the poem gets completely deprived of 
punctuation and, thenceforth, attains the colloquial and prayerful intonations simultaneously; secondly, all the punctuation marks are used in accordance with literary language norms; thirdly, the poet used punctuation marks instead of keywords, setting up a figure of ellipsis; finally, one or two marks (brackets, dashes, or commas) are prevalent.

Talking about free verse, punctuation marks can be not only the additional elements of composition and image-making, but also the intertextual symbols, like in Volodymyr Bazylev'sky's Punctuation:

\author{
Розділові знаки - изе більше \\ ніж розділові знаки. \\ Спроби від них відмовитися \\ Приречені на поразку... [3, p. 18]. \\ Пунктуацията е повече \\ От препинателни знаци. \\ Опитите да се откажем от нея \\ Са обречени на поражение... \\ (transl. by Vanya Angelova [3, p. 19]).
}

Because usage (or non-usage) of punctuation marks is qualified not as the universal constant of the free verse, but as the feature of a poet's individual style, their presence - or absence - allows confirming the following. Punctuation plays significant role in perception of a verse, conditions the amphiboly of the text, and helps a reader interpret its motifs and create one's own opinion about the poet's worldview. If the names of punctuation marks are present in a title, they serve to set up the 'expectation horizon' (H. R. Jauss) of the certain event or emotion [12, p. 15].

The circle of functions, primarily immanent to punctuation marks, gets widened in the imagination of a poet. By one's will, they become the factors of changes of seasons, existence of any limits and colors, heaven and earth themselves, but mainly - existence of poetry as a whole:

Стосовно ж поезії,

То крапки й коми,

Tupe ü deфic,

Лапки й дужки,

Знаки оклику й питання -

Ї̈ риштування й кріплення [3, p. 20]. 
It is interesting that Bazylevs'ky's image “глосолалія у виконанні анальфабета" (glossolalia performed by analphabet) in Bulgarian translation gets wonderfully transformed into "глосолалия, абсолютна анархия".

Upon exposing the symbolism of grapheme (a punctuation mark) in his verse, the poet not only considered the diverse complex of its primary meanings - particularly, correlations with separate words and clauses. He also gave it some new connotations based on either the shape of the mark or their syntactic and intonation functions (because, for Bazylevs'ky, the world would immerse into initial darkness without punctuation).

Viktor Teren's poem The Alphabet is not included into The Free Wind, but taken into consideration as the work consonant to the poem just analyzed. Its title should have constituted the expectation horizon of a scientific research or a talk over interpretations of letters; however, it is actually the verse novella whose plot is based on the collision of two contradictious languages, Ukrainian and Russian, at the concentration camp. The prisoners were made speak only Russian because “...всяк мусив знати / що ми там шепочемось" [14, p. 123].

Within The Alphabet, functions of letters are delegated to so-called 'forbidden,' firstly dialectal words: nouns "маржина" (herds), "бусол" (a stork), "вівчарик" (a shepherd boy), “трембіта" (a trumpet), "танашко" (the father), "вуйко" (an uncle), the verb "видиш" (уou see), the adverb "гілько" (only), the particle "гейби" (as if). On the one hand, $\mathrm{V}$. Teren's poem reveals the ancient taboos to pronounce the certain words (as to the text of the verse - to pronounce any Ukrainian word). On the other hand, the lexeme equalized to the letter turns out to be the part of 'invincible matter' (Bohdan-Inor Antonych), in other words - the element of Hutsul macrocosmos. In such a context 'Ukrainian alphabet,' symbolized by inveterate scars on the body of a narrator (old Hutsul), gets turned into runic script $[10$, p. 314]. Otherwise, this poem is correlated to another Teren's verse placed in The Free Wind - The Associations, whose imagery refers to 'camp' verse libres by Vasyl Stus as well:

Ти не знаєш, мій хлопчику, / що ялинка буває схожа / на визубні трат в намерзлому інеї, / вгорі п'ятикутна зірка. 
I до батька листи / на запітнілих шибках, підмальовані калачиками - /єдині, / які не читає ичензура.

I траєкторією викинутої цицарки / ставиться підпис під чиїмось життям [3, p. 132].

The poem Sunset (“Залези”) by Mina Karagyozova attracts our attention by its 'French' couleur, sounding like Veselyn Khanchev's masterpiece The Monmartre Vines. The latter should be cited here to compare:

Сам под черните покриви

Скита Вийон

Със сърие като къщите празно

И невидим зад своята масса в кръчмата

Тъгува Верлен...

И Лотрек, живописеиа,

Неполучил поръчка от никой богат чужденец...

(V. Khanchev [15, p. 141]).

Now let us look at Karagyozova's verse:

Колекиионирам залезите, в които теб те няма,

За да ти ги дам някой ден за подарък.

Събирам в нотна тетрадка мелодиите

На аккордеониста, който заедно с Едит Пиаф

За нищо не съжалява.

И мелодиите на китариста, който неси огън

От фламенкото и Пако де Лусия [3, p. 176].

As it is evident, V. Khanchev's speaker narrates on the urban background with grotesque hues (even heaven and earth are 'ferrous' over there), and thus creates the specific neo-romantic parallel between real (Monmartre boulevard) and dreamed worlds (Bulgaria where autumn had just begun).

The worlds of Khanchev's poem connected the persons of Francois Villon, Paul Verlaine, and Henry Toulouse-Lautrec, whose names became the collective image of artists - "poets, singers, and painters." The autochthonic Bulgarian word 'гроздобер' (vintage), used at the end of a pretty long verse, is a motif to erase the hues of 'emptiness, sorrow, and uselessness' from the images of aforesaid artists. The speaker of 
Mina Karagyozova creates her own world 'where we'll be together' the same way as Khanchev did, involving not only names of artists, but also their masterpieces: Edith Piaf's hit song Non Je Ne Regrette Rien and Paco de Lucia's Flamenco.

In conclusion, we can say that the $20^{\text {th }}$ century gave the technicolor picture of a real literary 'explosion' (as Maria Zubryts'ka said) which, on the one hand, evoked the whole avalanche of information; on the other hand, provoked the multiplied character of its comprehension. The diversity of objects and subjects to research and also the large quantity of means to scientifically interpret the creativity by a certain writer can be determined as the feature of today's 'creativogenous' society (according to Silvano Arieti). The other features of such a society are the equal access to cultural heritage; versatility of artistic groups and trends; aspiration to not only exist, but also achieve the set goals; free-available education; the absence of privileges for one groups and retentive attitude to others; intellectual tolerance, interactions and collaboration of creative personalities; the system of awards and bonuses.

Thanks to inexhaustible creative work of translators and editors of the anthology reviewed, Ukrainian and Bulgarian poets can reach the readers' souls so as start the emotional 'eye-to-eye' dialogue - just because neither artistic creation nor scientific communication are possible without it. Even if Nestor the Chronicler wrote his Tale of Bygone Years practically all alone, he constantly kept his future audience, or chytel'niks, as they were named in Baroque times, in mind. The question Where did the Russ land come from? is addressed to everyone of us, and we may answer it pretty simply, 'From the Language.' It is Language that was and yet will be the main identifier of esthetic sense and mentality of people, in our case - Ukrainians and Bulgarians.

1. Антология болгарской литературной критики / В. Д. Андреев, Х. П. Трандафилов (сост.). - Санкт-Петербург : Изд-во Санкт-Петерб. ун-та, 1998. $-384 \mathrm{c}$.

2. Базилевський В. О. „І зав'язь дум, і вільний лет пера...” Літературнокритичні статті, есе, студія одного вірша / В. О. Базилевський. - Київ : Рад. письменник, 1990. - 318 с. 
3. Вільний вітер: Антологія європейського верлібру / Волен вятьр: антология на европейския верлибър / упоряд. О. Гордон. Харків: Майдан, 2017. - 200 с.

4. Гайнічеру O. I. Поезія і мистецтво перекладу / О. І. Гайнічеру - Київ : Дніпро, 1990. - 212 с.

5. Грунський М. Розділові знаки / М. Грунський, М. Мироненко. - Харків : ДВУ, 1929. - 112 с.

6. Еленков К. Поети и поезия / К. Еленков. - София : Издателство „Народна младеж”, 1985. - 213 с.

7. Жовтис А. Л. Проблема свободного стиха и эволюция стихотворных форм: автореф. дис. ... д-ра филол. наук: 10.01 .08 / А. Л. Жовтис. Киев, 1975. - 45 с.

8. Жовтис А. Л. Стихи нужны... Избранные статьи / А. Л. Жовтис. Алма-Ата : Жазушы, 1968. - 270 с.

9. Любенов Л. Квадратура круга: перевод нерифмованного стиха / Л. Любенов // Перевод - средство взаимного сближения народов : сб. науч. трудов. - Москва : Прогресс, 1987. - С. 513-527.

10. Науменко Н. В. Серпантинні дороги поезії: природа та тенденції розвитку українського верлібру: монографія / Н. В. Науменко. - Київ : Видавництво „Сталь”, 2010. - 518 с.

11. Павличко Д. В. Наперсток / Д. В. Павличко. - Київ : Вид-во Соломії Павличко „Основи”, 2002. - 112 с.

12. Рейнгард И. А. Подтексты в стихосложении : учеб. пособие / И. А. Рейнгард. - Днепропетровск : Изд-во ДГУ, 1996. - 87 с.

13. Россельс В. Сколько весит слово. Статьи разных лет / В. Россельс. Москва : Сов. писатель, 1984. - 432 с.

14. Терен В. Твій день на землі: Вірші. Поеми. Вірші для дітей. Проза / В. Терен ; післямова В. Дробота. - Київ : Вид-во імені Олени Теліги, 2001. $-520 \mathrm{c}$.

15. Ханчев B. Лози в Монмартр / В. Ханчев // 100 шедьоври на Българската поезия. - София: Издателство къща СИЕЛА, 1999. - С. 100-101.

\title{
ПОПЫТКА СВОБОДЫ: СОВРЕМЕННЫЕ АНТОЛОГИИ УКРАИНСКОГО СВОБОДНОГО СТИХА
}

\author{
Наталия Валентиновна Науменко \\ orcid.org/0000-0002-7340-8985 \\ lyutik.0101@gmail.com \\ Доктор филологических наук, профессор \\ Кафедра иностранных языков профессионального направления \\ Начиональный университет пищевых технологий \\ Ул. Владимирская, 68, 01601, г. Киев, Украина
}


Аннотация. Путем медленного прочтения образцов украинской верлибристики XX века и ее переводов на болгарский (и наоборот переводов болгарского верлибра на украинский язык) показано, что она является примером довольно активного и гибкого применения натурфилософского образа в художественной ткани стихов. Это различные композиционные функции, которые он может выполнять (от декорирования лирического повествования до выражения сущности, идеи произведения), и стилистические приемы (сопоставление явлений природы и состояний человеческой души, антитезы образов природы), и создание новых коннотаций на основе традиционных значений. Материалом для рассмотрения в данной статье послужила опубликованная в 2017 г. в Харькове антология верлибра „Вільний вітер. Волен вятьр”. Данное издание хороший повод для одних ознакомиться с болгарской культурой, а для других актуализировать свои представления либо воспоминания об этой причерноморской стране. Изучение интерпретаций традиционных жанров, их поэтики в композиции на языке украинских, а также болгарских свободных стихов (в частности, помещенных в „Вільному вітрі”) позволило констатировать: чем глубже проникает автор во внутреннее измерение жизни лирического героя и его отношений с окружающим миром, выраженных в конкретной жанровой форме, тем шире становится круг значений культурного концепта (образа, символа) и тем просторнее исследовательское поле открывается для сопоставления этих значений в разных языках и литературах.

Ключевые слова: украинская и болгарская поэзия, верлибр, перевод, антология, стиль, жанр, язык.

\title{
СПРОБА СВОБОДИ: СУЧАСНІ АНТОЛОГІЇ УКРАЇНСЬКОГО ВІЛЬНОГО ВІРША
}

\author{
Наталія Валентинівна Науменко \\ orcid.org/0000-0002-7340-8985 \\ lyutik.0101@gmail.com
}

Доктор філологічних наук, професор

Кафедра іноземних мов професійного спрямування

Національний університет харчових технологій

Вул. Володимирська, 68, 01601, м. Київ, Україна

\begin{abstract}
Анотація. Шляхом повільного прочитання зразків української верлібристики XX століття та iii перекладів болгарською (i навпаки перекладів болгарського верлібру українською мовою) показано, що вона репрезентує досить активне і гнучке застосування натурфілософського образу в художній тканині віршів. Це й різні функції, які він може виконувати (від


декорування ліричної оповіді до вираження сутності, ідеї твору), й стилістичні прийоми (зіставлення явищ природи зі станами людської душі, антитези природних образів), і творення нових конотацій на грунті традиційних значень. Варіативність образності зумовила розмаїття жанрових репрезентацій верлібру, серед яких - філософська лірика, фольклорноорієнтовані замовляння та заклинання, стилізації східної поезії, абеткові вірші. Вивчення інтерпретацій традиційних жанрів, їхньої поетики в композиції та мові українських, а також болгарських вільних віршів зокрема, вміщених у „Вільному вітрі” (Харків, 2017) - дозволило констатувати: чим глибше проникає автор у внутрішній вимір життя ліричного героя та його відносин із довкіллям виражених у конкретній жанровій формі, тим ширшим стає коло значень культурного концепту (образу, символу), тим просторіше дослідницьке поле відкривається для зіставлення цих значень у різних мовах і літературах.

Ключові слова: українська та болгарська поезія, верлібр, переклад, антологія, стиль, жанр, мова.

\section{References}

1. Antologiya bolgarskoy literaturnoy kritiki [The Anthology of Bulgarian Literary Criticism]. Saint Petersburg, 1998, 384 p. (in Russian).

2. Bazylevs'ky V. I zavyaz' dum, i vil'nyi let pera: literaturno-krytychni statti, ese, studiya odnoho virsha [The Sprouts of Thought and Free Flight of the Pen: Literary Critical Articles, Essays, Studies of One Verse]. Kyiv, 1990, 318 p. (in Ukrainian).

3. Vil'nyi viter: Antologiya yevropeys 'koho verlibru / Volen vyatr: Antologia na yevropeyskiya verlibr [The Free Wind: The Anthology of European Vers Libre]. Kharkiv, 2017, 200 p. (in Ukrainian and Bulgarian).

4. Hainicheru O. Poeziya $i$ mystetstvo perekladu [Poetry and the Art of Translation]. Kyiv, 1990, 212 p. (in Ukrainian).

5. Hruns'ky M., Myronenko M. Rozdilovi znaky [Punctuation Marks]. Kharkiv, 1929, 112 p. (in Ukrainian).

6. Elenkov K. Poeti i poeziya. Sofia, 1985, 213 p. (in Bulgarian).

7. Zhovtis A. Problema svobodnogo stikha i evolutsia stikhotvornykh form [The Problem of the Free Verse and Evoution of Versification Forms]. Synopsis of the Doctorate Thesis. Kyiv, 1975, 45 p. (in Russian).

8. Zhovtis A. Stikhi nuzhny... Izbrannye statyi [The Poems Needed... Selected Articles]. Alma-Ata, 1968, 270 p. (in Russian).

9. Lyubenov L. Kvadratura kruga: perevod nerifmovannogi stikha [Quadrature of the Circle: Over the Translation of Non-Rhymed Verse]. In: Perevod sredstvo vzayimnogo sblizheniya narodov [Translation as the Means to Mutual Vicinage of Peoples]. Moscow, 1987, pp. 513-527. (in Russian). 
10. Naumenko N. Serpantynnhi dorohy poeziyi: pryroda ta tendentsiyi rozvytku ukrayins 'koho verlibru [Serpentine Roads of Poetry: Nature and Tendencies of Development of Ukrainian Vers Libre]. Kyiv, 2010, 518 p. (in Ukrainian).

11. Pavlychko D. Naperstok [The Thimble]. Kyiv, 2002, 112 p. (in Ukrainian).

12. Reinhard I. Podteksty $v$ stikhoslozheniyi [Subtexts in Versification]. Dnipropetrovsk, 1996, 87 p. (in Russian).

13. Rossels V. Skol'ko vesit slovo. Statyi raznykh let [How Much Weighs the Word. Articles of Various Years]. Moscow, 1984, 432 p. (in Russian).

14. Teren V. Tviy den' na zemli: Virshi. Poemy. Virshi dlya ditey. Proza [Your Day on the Earth: Poems. Long Poems. Verses for Children. Prose Writings]. Kyiv, 2001, 520 p. (in Ukrainian).

15. Khanchev V. Lozi v Monmartr [The Monmartre Vines]. In: 100 shedyovri na Bulgarskata poeziya [100 Masterpieces of Bulgarian Poetry]. Sofia, 1999, pp. 100-101. (in Bulgarian).

\section{Suggested citation}

Naumenko N. An Endeavor of Freedom: Modern Anthologies of Ukrainian Free Verse. Pytannia literaturoznavstva, 2018, no. 98, pp. 175-190. doi: 10.31861/pytlit2018.98.175.

Стаття надійшла до редакції 15.10.2018 p. Стаття прийнята до друку 10.12.2018 р. 